IZA DP No. 7134

How Do Tougher Immigration Measures Impact Unauthorized Immigrants?

Catalina Amuedo-Dorantes

Thitima Puttitanun

Ana Martinez-Donate

January 2013 


\title{
How Do Tougher Immigration Measures Impact Unauthorized Immigrants?
}

\author{
Catalina Amuedo-Dorantes \\ San Diego State University \\ and IZA \\ Thitima Puttitanun \\ San Diego State University
}

\author{
Ana Martinez-Donate \\ University of Wisconsin-Madison
}

Discussion Paper No. 7134

January 2013

IZA
P.O. Box 7240
53072 Bonn
Germany

Phone: +49-228-3894-0

Fax: +49-228-3894-180

E-mail: iza@iza.org

\begin{abstract}
Any opinions expressed here are those of the author(s) and not those of IZA. Research published in this series may include views on policy, but the institute itself takes no institutional policy positions. The IZA research network is committed to the IZA Guiding Principles of Research Integrity.

The Institute for the Study of Labor (IZA) in Bonn is a local and virtual international research center and a place of communication between science, politics and business. IZA is an independent nonprofit organization supported by Deutsche Post Foundation. The center is associated with the University of Bonn and offers a stimulating research environment through its international network, workshops and conferences, data service, project support, research visits and doctoral program. IZA engages in (i) original and internationally competitive research in all fields of labor economics, (ii) development of policy concepts, and (iii) dissemination of research results and concepts to the interested public.
\end{abstract}

IZA Discussion Papers often represent preliminary work and are circulated to encourage discussion. Citation of such a paper should account for its provisional character. A revised version may be available directly from the author. 


\section{ABSTRACT \\ How Do Tougher Immigration Measures Impact Unauthorized Immigrants? ${ }^{1}$}

The recent impetus of tougher immigration-related measures passed at the state-level raises concerns about the impact of such measures on the migration experience, trajectory and future plans of unauthorized immigrants. In a recent and unique survey of Mexican unauthorized immigrants interviewed upon their voluntary return or deportation to Mexico, almost a third reports experiencing difficulties in obtaining social or government services, finding legal assistance or obtaining health care services. Additionally, half of them report fearing deportation despite all of them being unauthorized. When we assess how the enactment of punitive measures against unauthorized immigrants, such as E-Verify mandates, has impacted their migration experience, we find no evidence of a statistically significant association between these measures and the difficulties reported by unauthorized immigrants in accessing a variety of services. However, the enactment of these mandates infuses deportation fear and reduces inter-state mobility among voluntary returnees during their last migration spell, and helps curb deportees' intent to return to the United States in the near future.

\section{JEL Classification: F22, O15}

Keywords: immigration, policy, undocumented, illegal, unauthorized, Mexico

Corresponding author:

Catalina Amuedo-Dorantes

Department of Economics

San Diego State University

5500 Campanile Drive

San Diego, CA 92182

USA

E-mail: camuedod@mail.sdsu.edu

\footnotetext{
1 This study was funded by the National Institute of Child and Human Development (Grant: 1 R01HD046886-01A2).
} 


\section{Introduction}

Immigration is a complex issue that raises strong feelings. Concerns about whether border security and enforcement were tough enough were the greatest impediments to the passage of a much-needed comprehensive immigration reform back in 2006 and 2007. Since then, some states have taken immigration matters into their own hands and adopted employment verification (i.e. E-Verify) systems as a means to curtail the hiring of unauthorized workers. ${ }^{2}$ By 2010, more than a dozen states required that public agencies or public contract recipients used EVerify to determine employment eligibility for new hires, and four states had enacted E-verify mandates for all employers (Rosenblum 2011). This trend has only increased over time, with five additional states enacting E-Verify mandates in 2011. Moreover, some of the states with EVerify mandates in place have gone further and approved increasingly tougher measures that do not only pertain to the hiring of unauthorized immigrants but, rather, make it a misdemeanor crime for an alien to be without proper documentation, such as the well-known Arizona's Senate Bill $1070 .^{3}$ Nationwide, evidence of the increasingly hostile environment faced by unauthorized immigrants has also become evident through the dramatic increase in the number of deportations from 50,924 in 1995 to 387,242 in 2010 (over a six hundred percent increase in fifteen years). ${ }^{4}$

\footnotetext{
${ }^{2}$ The E-Verify system was originally established by the Illegal Immigration Reform and Immigrant Responsibility Act of 1996 as a voluntary pilot program. Logistically, E-Verify is an internet-based, free program run by the United States government that compares information from an employee's employment eligibility verify form (I-9) to data from U.S. government records. If the information matches, that employee is considered eligible to work in the United States. If there is a mismatch, E-Verify alerts the employer and the employee is allowed to work while the problem is resolved.

${ }^{3}$ Georgia, Alabama and Utah are some of the states have followed Arizona, passing laws that expand the power of local police to check the immigration status of residents. Alike bills have been passed by at least one chamber of state legislatures in Indiana, Oklahoma and South Carolina. In total, up to 30 states are contemplating passing similar measures.

${ }^{4}$ Office of Immigration Statistics, U.S. Department of Homeland Security, 2010 Yearbook of Immigration Statistics. Available at www.dhs.gov/xlibrary/assets/statistics/yearbook/2010/ois_yb_2010.pdf. See Menjivar and Abrego (2012) for more information on the dramatic increase in deportations taking place nationally.
} 
Yet, all these measures might only reduce unauthorized immigration if they seriously deteriorate the migration experience of undocumented immigrants. While one might assume they do, we still lack information on the extent to which the adoption of more punitive measures against unauthorized immigrants is correlated to: (a) heightened deportation fear or difficulties in accessing social, legal or health care services, (b) increased or restricted mobility across state lines, ${ }^{5}$ or (c) a curbed intent to come back to the United States in the near future among voluntary returnees or deported migrants.

In this paper, we exploit a recent and unique survey of unauthorized Mexican immigrants interviewed in 2009 upon their voluntary return or deportation to Mexico to learn about the impact of tougher immigration measures, as captured by the enactment of E-Verify mandates, on the migration experiences and migratory plans of that population. We focus on the impact of EVerify mandates for a couple of reasons. First, the core of our survey is administered before the implementation of alternative immigration measures, such as SB1070 in Arizona. Second, for the most part, SB1070-like measures were adopted as follow-up measures by the same states that had previously enacted an E-Verify mandate. As such, the enactment of E-Verify mandates is a good indicator of the more punitive atmosphere against unauthorized immigration taking place is some states throughout the U.S. that we are interested in addressing. Using that information, we address the following questions: Are unauthorized immigrants in our sample more likely to report having experienced fear of deportation or difficulties in accessing various types of services following the enactment of E-Verify mandates? Are they more or less likely to move across states lines in response to the enactment of E-Verify mandates? And, do these mandates curb their intent to return to the United States in the near future? Answers to these questions are

\footnotetext{
${ }^{5}$ See Rosenblum and Gorman (2010).
} 
of great relevance for the ongoing debate on the impact of this type of legislative measures and on their effectiveness in ultimately curbing repetitive crossings by unauthorized immigrants allegedly the largest component of overall apprehensions (Cornelius 1998, Spener 2001, Sherry 2004). If existent, first order effects should be observed among unauthorized immigrants exposed to these more punitive measures, whereas second order effects may expand to future unauthorized immigrants contemplating migrating to the United States.

\section{Brief Literature Review}

A large number of studies have examined the impact of federal immigration laws, such as the 1986 Immigration Reform and Control Act (IRCA), on the flow of unauthorized immigrants. Most of that literature looks at changes in aggregate series (frequently apprehension data) before and after the enactment of the law. ${ }^{6}$ Others use individual level data on small or local samples from specific Mexican communities at certain periods of time, ${ }^{7}$ or rely on individual level data collected from a large number of Mexican communities over an extended period of time. ${ }^{8}$ Overall, regardless of the data source being used, most of these studies conclude that the enhanced border enforcement accompanying the implementation of such laws did not seem to have much of an impact on illegal immigration. Instead, it had the unintended

\footnotetext{
${ }^{6}$ Examples of these analyses are the works by Bean et al. (1990), Espenshade (1990), White et al. (1990), Bean, Edmonston, and Passel (1990), Singer and Massey (1988), Espenshade (1994), Cornelius (1998), Hanson and Spilimbergo (1999), Davila et al. (2002), and Orrenius and Zavodny (2003).

${ }^{7}$ See, for example, Cornelius (1989, 1990), Gonzalez and Escobar (1990), Massey et al. (1990), Chavez et al. (1990), Bustamante (1990) and Kossoudji (1992).

${ }^{8}$ For instance, Donato et al. (1992) and Orrenius (2001) rely on data from the Mexican Migration Project (MMP) to examine changes in the likelihood of a variety of events -such as taking a first illegal trip, repeat migration, being apprehended, using a border smuggler or coyote, and changes in smuggling costs or border-crossing sites- before and after the 1986 Immigration Reform and Control Act (IRCA). Angelucci (2005) also relies on MMP data to assess the impact of border enforcement on net flows (i.e. coming into and exiting the U.S.) of illegal Mexicans. Ritcher et al. (2007), however, use data from the Encuesta Nacional a Hogares Rurales de Mexico (ENHRUM) to examine the impact of three policies: IRCA, NAFTA, and increased border enforcement expenditures on migration. And Amuedo-Dorantes and Bansak (2011) rely on data from the Encuesta sobre Migración en la Frontera Norte de México (EMIF) to explore how changes in border enforcement helped deter undocumented migrants from repetitively attempting to cross the Mexico-U.S. border.
} 
consequence of prolonging unauthorized immigrants' migratory spells in the United States (Massey et al. 2002), as well as disrupting remittances and family ties (Hagan et al. 2008).

Likewise, a fairly large number of studies have examined the impact of federal laws, such as the Illegal Immigration Reform and Immigrant Responsibility (IIRIRA) or the Personal Responsibility and Work Opportunity Reconciliation Act (PRWORA) of 1996, on unauthorized immigrants' access to services and deportation fear. Under PRWORA, unauthorized immigrants continued not being eligible for any retirement, welfare, health, disability or any other similar benefit provided by an agency of a state or local government. Exceptions included emergency medical services funded through Medicaid and immunizations of communicable diseases. Title IV of the act referred to legal immigrants' (noncitizen permanent residents) eligibility for public benefits. Yet, due to unfamiliarity with the law and the U.S. health care system, fear of deportation, and language barriers, among other things, it was believed that this type of measure could have had the potential of severely restricting unauthorized immigrants' ability to access health services. ${ }^{9,10}$ In this vein, Ku (2009) finds that restrictions placed by welfare reform reduced the share of both legal as well as undocumented immigrants using Medicaid. Likewise, Rodriguez and Hagan (2004) and Hagan et al. (2010) find that increased enforcement following IIRIRA and PRWORA created anxiety, stress and confusion, leading immigrants to voluntarily withdraw from using public services for which they were entitled to. In contrast, Capps, Fix, and Anderson (2009) fail to find evidence of such a pattern after

\footnotetext{
${ }^{9}$ See Kullgren (2003), Rivers and Patino (2006), Bell (2004), Kaiser Commission on Medicaid and the Uninsured (2003), De la Torre and Estrada (2001), Schur and Albers (1996), Woloshin et al. (1995), and Solis et al. (1990) among others.

${ }^{10}$ More than 40 percent of immigrants are without health insurance (Bell, 2004). Kaiser Commission on Medicaid and the Uninsured (2003) finds that low-income immigrants are more than twice likely to be uninsured as lowincome citizens. Moreover, immigrants' health coverage varies by state. Uninsured immigrants ranged from 46 percent in California and New York to 56 percent in Texas during a 2001-2002 population survey by this agency.
} 
PRWORA. For instance, they document how the use of Medicaid among immigrants did not drop after welfare reform was passed.

More recently, after the bipartisan-fueled effort for a comprehensive immigration reform died in 2007, states have started to take action on these issues within their jurisdiction and researchers have been assessing the impact that state-level legislation has on unauthorized immigration. ${ }^{11}$ For example, Lofstrom, Bohn and Raphael (2011) explore how the passage and implementation of the 2007 Legal Arizona Workers Act (LAWA) altered the internal demographic composition of the resident population of the state. Despite the controversial efficacy of E-Verify, ${ }^{12}$ they find that LAWA, which required all employers to use the Federal EVerify system, reduced the shares of Hispanic non-citizens -a group more likely to be unauthorized- residing and working in the state of Arizona. In a similar line, Amuedo-Dorantes and Lozano (2011) examine the impact of Arizona’s SB1070. They find that SB1070 was enacted precisely as the population of likely unauthorized workers recovered in the state; thus suggesting that, while seemingly effective at deterring Hispanic non-citizen males, the effect of these legislations may be short-lived.

Yet, to this date, we still lack an understanding of the degree to which the passage of more punitive state-level measures against unauthorized immigrants increases their deportation fears or their experienced difficulties in getting government assistance, legal and health services. More importantly, even if they do, it is questionable whether unauthorized immigrants actually end up changing their migration trajectories and future plans on account of such policy measures.

\footnotetext{
${ }^{11}$ A comprehensive overview of state and local immigration policy-making in the United States can be found in Taking Local Control: Immigration Policy Activism in U.S. Cities and States, edited by Varsanyi (2010).

${ }^{12}$ Rosenblum (2011) discusses the strengths and weaknesses of the E-Verify system and discusses how E-Verify is highly vulnerable to identify fraud and employer noncompliance as documented by Westat Corporation (2009) and numerous audits by the Social Security Administration (SSA) Office of the Inspector General.
} 
These are important queries if one of the purposes of these state-level policy measures is to reduce unauthorized immigration and, as noted earlier, repetitive crossings by unauthorized immigrants are the largest component of overall apprehensions. In what follows, we try to shed some light on these questions using a unique database with detailed information on the recent migratory experiences and difficulties encountered by unauthorized Mexican immigrants, who compose by far the largest group among unauthorized immigrants residing in the United States by accounting for 58 percent of the total (Passel and Cohn 2011).

\section{Data}

In this study, we take advantage of data gathered between July 2009 and August 2010 from a cross-sectional, probability survey of migrants traveling through the Tijuana - San Diego border region. The survey, funded by the National Institutes of Health (NIH), is the result of a bi-national collaboration effort between the University of Wisconsin at Madison, the Center for Behavioral Epidemiology and Community Health (CBEACH) at San Diego State University and the Colegio de la Frontera Norte (COLEF) in Tijuana, Mexico. The survey is modeled after the large periodic survey of Mexican migrants known as the Encuesta sobre Migración en la Frontera Norte de México (EMIF) -a migration survey conducted by COLEF for the Secretaría del Trabajo y Previsión Social and the Consejo Nacional de Población along the United StatesMexico border (Secretaría del Trabajo y Previsión Social 1998). Like the EMIF, the survey methodology involves the use of probability sampling methods and the computation of similar survey weights -in our case to guarantee that the estimates based on survey data reflect the distribution of the socio-demographic characteristics and experiences of the migrant population 
crossing through the San Diego-Tijuana border. ${ }^{13}$ The San Diego - Tijuana region constitutes a natural port of entry to the State of California and accounts for 37 percent of the total migrant flow across the U.S.-Mexico border and 71 percent of the migrant flow in the West region of the United States-Mexico border. ${ }^{14}$

Individuals, who cross on foot, by train, car, bus and plane, are surveyed. During each survey shift, an interviewer applies a screening form that permits differentiating migrants from tourists and individuals born in the United States. Once a person is considered eligible (i.e. a migrant 18 years of age or older), the questionnaire is administered anonymously by a trained interviewer. Data are collected from 4 representative samples of Mexican migrant populations traveling through the San Diego-Tijuana border region: (1) Migrants returning to Mexico from the United States; (2) Migrants traveling North from other Mexican regions; (3) Migrants arriving at Tijuana from other Mexican border cities; and (4) Unauthorized migrants deported by the U.S. Border Patrol. The second population (that is, group (2)) arrives at the border region as their final destination or as an intermediate site in their journey to the United States. The other three populations arrive at Tijuana from the United States or from other Mexican border cities most of the times in their journey home or back to the United States. We focus on unauthorized immigrants from groups (1), (3) and (4) for whom detailed information regarding encountered difficulties in accessing a variety of services during their last trip to the United States is gathered. ${ }^{15}$ Our sample thus consists of individuals who are 18 years old and older, not born in

\footnotetext{
${ }^{13}$ Please refer to the appendix for more detailed information on the survey methodology.

${ }^{14}$ See: Secretaría de Gobernación, Consejo Nacional de Población, Instituto Nacional de Migración, Secretaría de Relaciones Exteriores, Secretaría del Trabajo y Previsión Social, El Colegio de la Frontera Norte. 2007. Encuesta sobre migración en la Frontera Norte de Mexico, Serie Anualizada 2000-2007.

${ }^{15}$ Unlike migrants in groups (1) and (4), who are return migrants, or migrants in group (3), who have resided in the border region and have often crossed to the United States before, the vast majority of individuals in group (2) do not have previous U.S. migratory experience and, as such, they are not inquired about their experiences in obtaining needed services while in the United States.
} 
the United States, who last migrated to the United States illegally with the intent of staying over one month. Overall, we work with a sample of approximately 1,233 unauthorized Mexican migrants returning from the United States, either voluntarily or involuntarily after being deported.

It is important to recognize that, despite providing us with recent and relevant information about the struggles of unauthorized migrants while in the United States, our dataset lacks information on three groups of unauthorized Mexican emigrants traveling through the San Diego-Tijuana region. In addition to any unauthorized migrant in group (2) with past U.S. migration experience, we lack information on unauthorized Mexican emigrants who return to interior points in Mexico via air. However, because migrants traveling to interior points of Mexico via air are less likely to be unauthorized, this deficiency is not likely to greatly compromise our final results. The third category omitted from the survey is that of unauthorized Mexican emigrants who never return to Mexico. Due to the proximity between the two countries, returnees still account for a rather large group (Lowell and de la Garza 1992, Lindstrom 1996, Reyes 1997, and Orrenius 1999). ${ }^{16}$ Yet, the lack of data on non-returnees restricts our ability to extrapolate our findings to the overall population of unauthorized immigrants. Unfortunately, no survey fully captures all unauthorized immigrants -that is, those staying in the United States and those returning home, along with information on the outcomes object of study. ${ }^{17}$ However, we can try to assess the consequences of the sample selection bias

\footnotetext{
${ }^{16}$ This hypothesis is supported by the fact that other surveys - such as the Mexican Migration Project (MMP at www.pop.upenn.edu/mexmig/databases/databases.htm), in their attempt to get a representative sample of Mexican migrants, interview a relatively small number of Mexican migrant households residing in the United States, while the vast majority of households with U.S. migration experience are interviewed in Mexico.

${ }^{17}$ Indeed, even surveys that interview migrants both in Mexico and in the United States, as is the case with the Mexican Migration Project (MMP), lack data on the questions object of study, as is the case with encountered difficulties, deportation fears, inter-state mobility, and the intent to go back to the United States in the foreseeable future.
} 
incurred from lacking information on non-returnees. We do so by carrying out the analysis separately for unauthorized immigrants who return voluntarily and for deported immigrants. Like non-returnees, deported migrants do not wish to return back to Mexico. As such, a comparison of our estimates for voluntary returnees and deported migrants can shed some light on the bias incurred from lacking information on non-returnees with return intentions that diverge from those of voluntary returnees.

\section{Some Descriptive Evidence}

Table 1 provides some summary statistics for the population of unauthorized immigrants captured by the survey. Because of probable differences between unauthorized immigrants who voluntarily choose to go back and those deported, we report these descriptive statistics separately for each sample. In many respects, unauthorized immigrants in both samples are rather similar. For instance, the vast majority are migrant men on average 31 to 32 years old. ${ }^{18}$ Educational attainment is relatively low. About a third has a primary education (i.e. has only attended elementary school), followed by another third with a secondary education (i.e. has attended up to middle school) and slightly more than 20 percent with Preparatoria (i.e. has attended up to high school). Only 4 to 5 percent has an educational attainment higher than Preparatoria, and a slightly smaller share (around 2 to 3 percent) has no education at all. On average, they have crossed to the United States 3 times. Approximately 25 percent of them worked in the United States during their last migration spell, ${ }^{19}$ and 3 percent resided in what we refer to as "poor housing”, 20 Lastly, most immigrants last entered the United States after 2005. Nevertheless,

\footnotetext{
${ }^{18}$ Due to the small number of women in our sample, we also carried the analysis using only men. Results, available from the authors upon request, were robust to the use of that alternative sample.

${ }^{19}$ The low unemployment rate follows from the fact that the samples used in this paper are undocumented returnees, many of them deported while crossing or voluntarily returning home after not finding work.

${ }^{20}$ The latter includes a mobile home, homeless shelter, halfway house or boarding home, car or truck, on the streets.
} 
since some return to Mexico after being in the United States more than 20 years, the average duration of the last migration spell ranges between 6 and 7 years.

There are, however, some notable differences between the two groups that justify their separate analysis. Most of these relate to their marital status, living arrangements while in the United States, and past migratory experiences. Unauthorized immigrants who voluntarily return home are approximately 13 percentage points more likely to be married than their deported counterparts. Likewise, about 47 percent of voluntary returnees report having lived with a partner while in the United States relative to 38 percent of deported immigrants. Yet, a smaller share of voluntary returnees lived with children while in the United States compared to deported immigrants. Finally, while both groups of migrants report crossing to the United States an average of three times, deported migrants have been apprehended and returned to Mexico twice as opposed to once in the case of voluntary returnees.

Of particular interest to us is the impact of E-Verify mandates on the experiences and migratory decisions of unauthorized immigrants in our sample. We use state-level data on the enactment dates of E-Verify mandates from the National Conference of State Legislatures (NCSL) to create a dummy variable (i.e. E-Verify) equal to 1 if the migrant was headed to a state with an E-Verify mandate adopted prior to her/his arrival or the state adopts an E-Verify mandate during her/his migration spell. Approximately 6 percent of voluntary returnees fall in that category, as opposed to 9 percent of deported immigrants. As a result, despite our small sample size, this could result in differences between the migratory experiences of unauthorized immigrants who voluntary return home and those of their deported counterparts.

Table 2 reports on the migratory experiences of unauthorized immigrants. Specifically, since the first aim of this study is to examine the extent to which the adoption of tougher 
immigration policy measures is correlated to a heightened deportation fear or to increased difficulties in accessing government assistance, health care or legal services, we focus on the following survey items:

Thinking about your most recent stay in the United States, please tell me if you agree with the following statements:

1. You thought you would be deported if you went to a social or government agency.

2. You experienced difficulties in finding legal services due to your legal status. ${ }^{21}$

3. You experienced difficulties in obtaining health care due to your legal status.

4. $\quad$ You feared being deported.

We use respondents' endorsement of these statements to create a set of dummy variables capturing the prevalence of such difficulties as well as that of deportation fear -namely: Difficulties in getting government assistance, Difficulties in finding legal services, Difficulties in obtaining health care services, and Fear of deportation. ${ }^{22}$

Table 2 displays the mean values for the aforementioned variables for unauthorized immigrants according to whether or not they returned to Mexico voluntarily or involuntarily (that is, whether or not they were deported). A couple of points are worth making. First, for the most part, the reported incidence of the various difficulties and deportation fear being examined does not significantly vary with the type of return. The only exception being difficulties in finding legal services, which appear to be experienced by a 5 percentage-point higher share of deported migrants than by their non-deported counterparts -although the difference is only statistically

\footnotetext{
${ }^{21}$ These refer to difficulties in finding legal assistance when encountering difficulties in renting, when being discriminated against or when being abused, for example.

22 The various categories of encountered difficulties originate from different scales of acculturative stress used in the literature (e.g. Finch et al. 2001, 2003; Finch and Vega 2003; Marin et al. 1987; Norris, Ford and Bova 1996; and Wallen, Feldman and Anliker 2002).
} 
significant at the 10 percent level. Second, half of unauthorized immigrants report experiencing fear of deportation and almost a third of them documents experiencing difficulties in accessing legal, health or government related services during their most recent migration spell. Hence, from the figures in Table 2, we would infer that, while a non-negligible share of unauthorized migrants reports experiencing deportation fear or difficulties in getting government assistance, finding legal services or obtaining health care services during their last migration spell due to their legal status, the vast majority does not. This is true even in the midst of an increasingly hostile environment against unauthorized immigrants.

Our second aim is to explore how the enactment of tougher state-level immigration measures, such as E-Verify mandates, impact the mobility of unauthorized migrants as captured by: (a) their inter-state migration, and (b) their intentions to come back to the United States in the near future. Table 2 provides some information on the share of unauthorized immigrants in our sample who move across state lines as captured by residing most of their migration spell in a state different from the one they report being headed to when they last migrated. Given the greater share of deported immigrants headed to a state with an E-Verify mandate adopted prior to or during their migration spell, it may not be surprising that 19 percent of them report having moved across state-lines relative to 14 percent of voluntary returnees. The difference is statistically different from zero at the 5 percent level. Table 2 also informs on unauthorized migrants' intentions to return to the United States. Perhaps not surprisingly given that their migration spell was cut short due to apprehension, a significantly larger percentage of deported immigrants (75 percent) report planning to come back to the United States in the near future, compared to 67 percent of voluntary returnees. 


\section{Methodology}

Our main objective is to address the following questions: (1) Is the enactment of E-Verify mandates correlated to an intensified fear of deportation or to increased difficulties in accessing various types of services among unauthorized immigrants in our sample? (2) Are such punitive measures correlated to their increased mobility across state lines? And, more importantly, (3) do they ultimately curb their intent to come back to the United States in the near future?

To answer the aforementioned questions, we exploit the variation in the enactment of EVerify mandates over time and across states. Specifically, to assess how more punitive legislation towards unauthorized immigrants impacts: (a) the likelihood of experiencing fear of deportation or difficulties in getting government assistance, finding legal services or obtaining health care services; as well as (b) the likelihood of moving across states, we estimate the following equation:

$$
Y_{i s t}=\alpha+\beta \text { EVerify }_{s t}+X_{i s t} \gamma+\delta_{s}+\phi_{t}+\delta_{s} t+\varepsilon_{i s t}, \varepsilon_{i s t} \sim N\left(0, \sigma^{2}\right)
$$

where $Y_{i s t}$ is the dependent variable equal to 1 if the unauthorized migrant $i$, who last migrated to state $s$ in year $t$, indicates having experienced: (a) fear of deportation or difficulties experienced in seeking various types of services, or (b) has moved across state lines. ${ }^{23}$ E-Verify st is a dummy variable equal to 1 if the migrant was headed to a state with an E-Verify mandate adopted prior to her/his arrival or the state adopts an E-Verify mandate during her/his migration spell. For example, E-Verify $y_{s t}$ equals 1 if the migrant was headed to Arizona -a "treated state"- and last entered the United States on/after July 2007 -the "treatment date" for Arizona. ${ }^{24}$ Likewise, it

\footnotetext{
${ }^{23}$ We do not have information on all moves across state lines. We know, however, the state where the migrant was headed to when they last entered the United States, as well as the state in which they spent most of their migration spell. We use that information to identify mobility across state lines during their last migration spell.

${ }^{24}$ E-Verify was mandated in Arizona in July 2007 (see: http://www.ncsl.org/issues-research/immig/2011-state-lawsaddressing-e-verify.aspx). We use the enactment dates of E-Verify mandates, regardless of their scope.
} 
equals 1 if the migrant was headed to Arizona before July 2007 and s/he reports being in the United States beyond that date. However, it equals 0 if the migrant was headed to Arizona before July 2007 and returned to Mexico before that date, or if s/he was headed to a "nontreated” state, such as California. ${ }^{25}$ Therefore, our primary interest is $\beta$, which captures how EVerify mandates may be impacting the deportation fear, difficulties in obtaining services, and mobility across state lines of our sample of unauthorized immigrants during their last U.S. migration spell.

Additionally, the analysis includes the demographic and migration-related controls displayed in Table 1 in vector $X$, as well as a battery of state fixed-effects, last year of entry fixed-effects, and state-level time trends. The fixed-effects are intended to account for a wide range of regional and macroeconomic factors potentially correlated to the experiences and migratory choices of this population and the passage of an E-Verify mandate by a particular state. Examples include residing in a state with a large share of unauthorized immigrants, who are likely to provide an information network and a safety net that lowers migration costs and the likelihood of reporting difficulties in obtaining services. Alternatively, an economic downturn can damage state budgets, reduce the availability of services, and deteriorate the labor market prospects of unauthorized immigrants -all of which can impact the likelihood of reporting difficulties in obtaining services and future migratory decisions. Finally, state-level time trends help capture changing socio-economic or political characteristics at the state level potentially

\footnotetext{
${ }^{25}$ The vast majority of our sample, modeled after the EMIF, was headed to California (75.26 percent) and Arizona (6.81 percent) during their last visit.
} 
correlated to the outcomes being examined, such as changing immigration inflows or other immigration policies to a particular state over time. ${ }^{26}$

Note that the decision to voluntarily return to Mexico may depend on experienced difficulties while in the United States; just as the likelihood of being apprehended and deported could be a byproduct of the migrant's mobility within the United States. Due to those endogeneity concerns, we cannot pool deportees and voluntary returnees and include a dummy indicative of how their migration spell ended in order to differentiate between the two groups. Instead, the models are estimated separately for voluntary returnees and for deported migrants. This allows us to assess: (a) whether they significantly differ with regards to their mobility across state lines or with regards to their likelihood of experiencing deportation fear or difficulties in obtaining some services, and (b) the extent to which E-Verify mandates impacted the aforementioned outcomes differently for the two groups of immigrants.

To conclude, we examine how the adoption of more punitive measures against unauthorized immigrants impacts the intent to come back to the United States in the near future expressed by returnees by estimating the following equation:

$$
Y_{i s t}=\alpha+\beta_{1} \text { EVerify }_{s t}+\beta_{2} \text { Deported }_{\text {ist }}+\beta_{3} \text { EVerify }_{s t} * \text { Deported }_{i s t}+X_{i s t} \gamma+\delta_{s}+\phi_{t}+\delta_{s} t+\varepsilon_{i s t} \text {, }
$$

where $\varepsilon_{i s t} \sim N\left(0, \sigma^{2}\right)$ and $Y_{i s t}$ denotes the declared intent to return to the United States in the near future of migrant $i$, who last migrated to state $s$ in year $t$. Because the intention to come back to the United States in the near future depends, to a large extent, on how the last migration spell ended, equation (2) includes a dummy variable to identify if the migrant was apprehended

\footnotetext{
${ }^{26}$ Examples of the latter include any ICE agreements with state law enforcement agencies under Section 287(g) of the Immigration and Nationality Act (INA).
} 
and deported (i.e. the variable: Deported), and is estimated for the pooled sample of returnees. ${ }^{27}$ To further assess if E-Verify mandates impact the migrant's declared intent to return to the United States in the near future differently for the two groups, the Deported and E-Verify dummies are interacted. Overall, our interest is on $\beta_{1}$ and $\beta_{3}$, which capture: (a) the impact of EVerify mandates on the reported intention to come back to the United States, and (b) the differential impact that the mandates might be having on voluntary returnees and deported migrants, respectively.

Lastly, we estimate equations (1)-(2) as linear probability models (LPMs). Although, in some instances, LPMs can yield predicted probabilities that fall outside the unit circle, they impose fewer restrictions on the distribution of the error term and facilitate convergence when working with small samples (Wooldridge 2008).

\section{Findings}

The main purpose of our study is to learn about how the enactment of tougher immigration measures, such as E-Verify mandates, is correlated to: (a) heightened deportation fears or increased difficulties in accessing government assistance, health care or legal services by unauthorized returnees, as well as to (b) their migratory choices. The latter are captured by:

their mobility across states lines while in the United States, and (2) their intention to come back to the United States in the near future.

\footnotetext{
${ }^{27}$ We also estimate equation (2) separately for voluntary returnees and deportees. Our main finding regarding the impact of E-Verify mandates on the intent to return to the United States proves robust. However, the model fails to document the very important role that deportation during the last migration spell plays in explaining the intention to cross again in the near future or the extent to which the enactment of an E-Verify mandate offsets such an impact.
} 


\section{(a) The Impact of E-Verify on Deportation Fear and Access to Services}

Table 3 displays the results from estimating equation (1) as a linear probability model of the likelihood of fearing deportation or experiencing difficulties in getting government assistance, finding legal services or obtaining health care services due to the lack of legal status. We distinguish between voluntary returnees and deported immigrants on the premise that voluntary returnees might significantly differ from their deported counterparts. After all, they choose to voluntarily go back to Mexico, whereas deported migrants do not. In that regard, deported migrants may look more alike other unauthorized immigrants who do not return to Mexico with regards to their intention to remain in the United States. As such, a comparison of the estimated impact of E-Verify mandates on the experiences of voluntary returnees and deported migrants can shed some light on the bias incurred from lacking information on nonreturnees with return intentions that diverge from those of voluntary returnees.

A couple of results are worth discussing. First, Chow tests reveal that, after we account for various individual characteristics, state and time fixed-effects, and state-level time trends, deported migrants and voluntary returnees significantly differ with regards to their migration experience in the United States. Specifically, deportees appear more likely to report fearing deportation and encountering difficulties in getting government assistance and legal services than voluntary returnees. ${ }^{28}$ These differences provide support for their separate analysis. Second, EVerify mandates do not appear to have a significant impact on the likelihood of experiencing difficulties in getting government assistance, finding legal services or obtaining health care services due to the lack of legal status. This is true regardless of what unauthorized immigrants'

\footnotetext{
${ }^{28}$ The F-statistics from the Chow tests determining whether there is a difference between deportees and voluntary returnees with regards to their experienced difficulties in getting government assistance, finding legal services, or with respect to experienced deportation fear are $3.23,4.33$, and 4.96 , respectively. They are statistically significant at 10 percent, 5 percent and 5 percent levels, respectively.
} 
return intentions were. Likewise, the enactment of E-Verify mandates does not seem to increase deportation fears among deported migrants. Nevertheless, it does raise deportation fear among voluntary returnees. In particular, a 1 percent increase in the share of voluntary returnees headed to a state with an E-Verify mandate in place prior to or during their migration spell -equivalent to half a percentage point increase in that share (see Table 1)- raises their likelihood of experiencing deportation fear by 3 percentage points to an average slightly above 50 percent (see Table 2). As such, it is only in that regard that the impact of E-Verify mandates appears to significantly differ between deportees and voluntary returnees. ${ }^{29}$

Table 3 also informs on other determinants of the likelihood of experiencing various types of difficulties in getting services or fearing deportation according to whether the migrant returned voluntarily to Mexico or was deported. In both instances, more educated individuals are anywhere between 6 and 26 percentage-points less likely to document limitations in acquiring government or health care related services than their less educated counterparts. In contrast, married migrants, as well as migrants who report living in the United States with a partner or with children, are between 8 and 27 percentage-points more likely to report experiencing fear of deportation or difficulties in accessing government assistance, legal or health care services. Other factors related to the likelihood of having experienced various types of difficulties in getting services or deportation fear include the individual's migratory history, which has a differential impact on deportees and voluntary returnees. For instance, voluntary returnees who frequently cross the border appear less likely to report difficulties in securing health services,

\footnotetext{
${ }^{29}$ The F-statistics from the Chow tests determining whether there is a difference in the impact of E-Verify on the experienced difficulties in getting government assistance, finding legal services, and health care services between deportees and voluntary returnees are $1.39,0.64$, and 0.46 , respectively. None of them is statistically significant at standard significance levels. The F-statistic from the Chow test determining whether there is a difference in the impact of E-Verify mandates on the experienced fear of deportation is 26.68, which is significant at the 1 percent level.
} 
whereas the opposite is true for their deported counterparts. Likewise, the number of previous deportations seems to be directly related to a higher likelihood of experiencing deportation fear and difficulties in obtaining services among voluntary returnees. Yet, the opposite appears to be the case among deported immigrants. Finally, having worked in the United States and having lived in relatively poor housing are positively correlated to a higher likelihood of experiencing deportation fear and various types of difficulties in securing services.

Overall, it is not surprising that migrants with more to lose owing to having a job or family responsibilities in the United States (as is more likely to be the case with those residing with a partner, children or reporting being married), as well as those in greater economic need (as might be the case with less educated immigrants or those residing in very poor housing), might be more likely to report experiencing difficulties in accessing services and, overall, fear of deportation. After all, they are more likely to seek such services. It is also interesting to see how the adoption of punitive measures against unauthorized immigrants, such as E-Verify mandates, does not seem to significantly worsen their experiences in acquiring services.

\section{(b) The Impact of E-Verify on Inter-state Mobility and Future Migration Plans}

Does the enactment of more punitive measures against unauthorized immigrants change their migratory decisions? In particular, are unauthorized immigrants more or less likely to move across state lines on account of such measures? And do they curb their intent to come back to the United States in a near future upon their return home as a result of a more hostile environment? Table 4 and Table 5 address the aforementioned questions. Specifically, Table 4 displays the results from estimating equation (1) to examine the likelihood of moving across states in response to the adoption of E-Verify mandates separately for voluntary returnees and deported immigrants. In that manner, we gauge the extent to which these two groups of migrants 
might differ with regards to their mobility patterns within the United States. Furthermore, we are able to assess if E-Verify mandates induce greater mobility on the part of unauthorized immigrants and, if so, whether such an impact differs according to the migrant's willingness to return home. With that purpose in mind, we perform two separate Chow tests. The first one tests for a difference between deportees and voluntary returnees with their regards to the decision to move across states, whereas the second tests for a difference between deportees and voluntary returnees with respect to the effect of E-Verify on the decision to move across states. According to the first Chow test, deported immigrants and voluntary returnees do differ with regards their internal mobility patterns, with the former exhibiting a higher likelihood of moving across state lines than the latter. ${ }^{30}$

In turn, the coefficient on the E-Verify dummy hints on the differential response of both groups to the adoption of tougher immigration measures by the state -voluntary returnees being more fearful to move than deportees. In particular, a 1 percent increase in the share of voluntary returnees headed to a state with an E-Verify mandate in place prior to or during their migration spell reduces their inter-state mobility by 1 percentage point -from an average of 14 to 13 percent. Therefore, E-Verify mandates display a statistically significant and differential impact on the internal mobility patterns of unauthorized returnees according to their intent to go back home. ${ }^{31}$ Why would E-Verify depress the internal mobility of voluntary returnees and not that of deported migrants? We can only hypothesize. We know that voluntary returnees appear to display a lower tendency to move across states than deportees. Perhaps, their increased fear

\footnotetext{
${ }^{30}$ The F-statistic from the Chow test determining whether there is a difference between deportees and voluntary returnees with regards to their decision to move across states is 8.06, which is significant at the 1 percent level.

${ }^{31}$ The F-statistic from the Chow test determining whether there is a difference with respect to the effect of E-Verify on the decision to move across states between deportees and voluntary returnees is 10.73 , which is significant at the 1 percent level.
} 
following the enactment of an E-Verify mandate (see Table 3) only serves to reinforce their lower inter-state mobility.

While the enactment of E-Verify mandates does not appear to significantly reduce the internal mobility patterns of deportees, educational attainment, having lived with a partner or kids while in the United States, having worked during their last visit and the length of their last migration spell are all factors that reduce their likelihood of moving across state lines. Among voluntary returnees, the only remaining factor associated to a greater internal mobility is being male. Specifically, male migrants are up to 7 percentage points more likely to move across state lines than their female counterparts.

Do E-Verify mandates help curb unauthorized returnees' desire to come back to the United States in a near future? Table 5 addresses this question with the estimation of equation (2). The effect of E-Verify mandates on the likelihood of indicating an intent to go back to the United States in the near future is essentially zero for voluntary returnees (the 0.03 coefficient is not statistically different from zero at standard significance levels). On the contrary, E-Verify mandates reduce that likelihood among deportees by $0.23(-0.26+0.03){ }^{32}$ How do these impacts compare to those of being the subject of deportation? Deportation significantly raises the likelihood of reporting an intention to return to the United States regardless of whether or not migrants reside in an E-Verify state. Deportees residing in non-E-Verify states will be 0.35 more likely to report planning to cross again, whereas deportees in E-Verify states will only be 0.09 more likely to report a similar intent. Therefore, the restraining effect of E-Verify mandates is still not large enough to offset the stimulating impact of a deportation.

\footnotetext{
${ }^{32}$ The coefficient estimates for Deported and E-Verify State*Deported are jointly significant at the 1 percent level.
} 
Other factors also appear to curtail the intent to come back to the United States. For instance, older returnees appear less likely to report planning to go back to the United States in the near future. However, more educated migrants, as well as those who lived with a partner or children while in the United States appear to be more interested in going back to the United States. Likewise, longer migration spells help raise the desire to try to cross again in the near future, just as deportations do. ${ }^{33}$

In sum, the passage of more punitive measures against unauthorized immigrants, like EVerify mandates, does not seem to significantly increase the difficulties experienced by unauthorized immigrants in securing services. ${ }^{34}$ However, it appears to infuse deportation fear and reduce the inter-state mobility among voluntary returnees, and partially lessen deportees' desire to return to the United States in the near future.

\section{Summary and Conclusions}

The recent impetus of tougher immigration-related measures passed at the state-level leads anyone to question their incidence and effectiveness in reducing unauthorized immigration. If anybody, unauthorized immigrants exposed to such measures should be the first ones to report being more fearful of deportation or having greater difficulties in securing a variety of services. Additionally, if effective, we would expect the newly adopted measures to alter unauthorized immigrants’ migratory plans -either by inducing or preventing them from moving across state lines, or by changing their intentions to come back to the United States in the foreseeable future.

\footnotetext{
${ }^{33}$ Deportations may not surprisingly increase the desire to return to the United States in the near future if, as noted by Hagan et al. (2008), they disrupt the stream of remittances and separate families.

${ }^{34}$ Our results are similar to Parrado (2012), which study the effect of the 287(g) program on the geographic dispersion of the Mexican immigrants. Parrado (2012) finds no direct impact of the program on the number of undocumented Mexican migrants in the locality.
} 
Using a recent and unique survey of Mexican unauthorized immigrants interviewed in 2009 upon their voluntary return or deportation to Mexico, we find that the adoption of punitive measures against unauthorized immigrants, such as E-Verify mandates, does not appear to increase the difficulties experienced by unauthorized immigrants in securing a variety of social, legal and health related services. However, the enactment of more punitive measures raises the likelihood of experiencing fear of deportation and reduces the internal mobility of voluntary returnees. Additionally, the mandates appear to partially curb deportees' intentions to come back to the United States in the foreseeable future.

As noted throughout the paper, due to the unfortunate lack of detailed data on undocumented immigrants, our findings need to be taken with caution. For instance, differences in the profile of migrants traveling through the San Diego-Tijuana versus other Mexican border towns might limit the generalizability of the study results, even if the San Diego-Tijuana border region concentrates about 37 percent of the total migrant flow across the U.S.-Mexico border. Another data limitation is the lack of detailed information on all moves across state lines, which leads us to use the information on the states migrants were headed to and the states they spent most of their time at during their last migration spell to create the inter-state mobility measure. More importantly, our findings pertain to unauthorized returnees and, as such, need to be taken with caution when trying to make inferences about the overall impact on the unauthorized population. We try to assess the consequences of the sample selection bias incurred from lacking information on non-returnees with return intentions that deviate from those of voluntary returnees for our findings. Our findings suggest that the impact of E-Verify mandates on the deportation fear and inter-state mobility of unauthorized immigrants would get closer to zero if unauthorized non-returnees were to be included. Possibly of greater importance given that 
repetitive illegal crossings constitute the largest component of overall apprehensions, is the fact that, while E-Verify mandates do curb deportees' intentions to go back to the United States in the near future, their impact is not large enough to overturn the stimulating impact or their past deportations on their re-migration plans. Therefore, overall, our findings cast some doubt on the effectiveness of tougher immigration policies if their intent is to curtail illegal immigration by deteriorating unauthorized immigrants' experiences in the United States and by, ultimately, curbing their desire to come back. 


\section{References}

Amuedo-Dorantes, Catalina and Cynthia Bansak. 2011. "The Effectiveness of Border Enforcement in Deterring and Postponing Repetitive Illegal Crossings Attempts”, unpublished manuscript.

Amuedo-Dorantes, Catalina and Fernando Lozano. 2011. “On the Effectiveness of SB1070 in Arizona”, unpublished manuscript.

Angelucci, Manuela. 2005. "U.S. Border Enforcement and the Net Flow of Mexican Illegal Migration”, IZA Discussion Paper No. 1642.

Bean, Frank, Barry Edmonston, and Jeffrey S. Passel. (eds.). 1990. Undocumented Migration to the United States: IRCA and the Experience of the 1980s. Washington, DC: Urban Institute.

Bean, Frank D., Thomas J. Espenshade, Michael J. White, and Robert F. Dymowksi. 1990. "Post-IRCA Changes in the Volume and Composition of Undocumented Migration to the United States: An Assessment Based on Apprehension Data”, pp. 111-58 in Undocumented Migration to the United States: IRCA and the Experience of the 1980s, edited by Frank D. Bean, Barry Edmonston, and Jeffrey S. Passel. Washington, DC: Urban Institute.

Bell, Melissa T. 2004. “Immigrants' Access to Quality Health Care” Trends Alert: Critical Information for State Decision-Makers. The Council of State Governments, September 2004.

Bustamante, Jorge A. 1990. "Measuring the Flow of Undocumented Immigrants: Research Findings from the Zapata Canyon Project”, pp. 211-26 in Undocumented Migration to the United States: IRCA and the Experience of the 1980s, edited by Frank D. Bean, Barry Edmonston, and Jeffrey S. Passel. Washington, DC: Urban Institute.

Capps, Randy, Michael E. Fix, and Everett Henderson. 2009. “Trends in Immigrants' Use of Public Assistance after Welfare Reform”, pp. 123-52 in Immigrants and Welfare: The Impact of Welfare Reform on America's Newcomers, edited by Michael Fix. New York, NY: Russell Sage Foundation.

Chavez, Leo R., Estevan T. Flores, and Marta Lopez-Garza. 1990. "Here Today, Gone Tomorrow? Undocumented Settlers and Immigration Reform” Human Organization, 49: 193205.

Cornelius, Wayne A. 1989. "Impacts of the 1986 U.S. Immigration Law on Emigration from Rural Mexican Sending Communities”, Population and Development Review, 15: 689-705.

Cornelius, Wayne A. 1990. "Impacts of the 1986 U.S. Immigration Law on Emigration from Rural Mexican Sending Communities”, pp. 227-50 in Undocumented Migration to the United States: IRCA and the Experience of the 1980s, edited by Frank D. Bean, Barry Edmonston, and Jeffrey S. Passel. Washington, DC: Urban Institute. 
Cornelius, Wayne A. 1998. “The Structural Embeddedness of Demand for Mexican Immigrant Labor: New Evidence from California” in Marcelo Suárez-Orozco (ed.), Crossings: Mexican Immigration in Interdisciplinary Perspective. Cambridge, MA: Harvard University Press/David Rockefeller Center for Latin American Studies, pp. 114-144.

Dávila, Alberto, José A. Pagán and Gökçe Soydemir. 2002. “The Short-term and Long-term Deterrence Effects of INS border and interior enforcement on undocumented immigration”, Journal of Economic Behavior \& Organization, 49: 459-72.

De la Torre, Adela and Antonio L. Estrada. 2001. “Mexican Americans and Health”, The University of Arizona Press, Tucson, AZ.

Donato, Katherine M., Jorge Durand, and Douglas S. Massey. 1992. "Stemming the Tide? Assessing the Deterrent Effects of the Immigration Reform and Control Act”, Demography, 29(2): 139-57.

Espenshade, Thomas J. 1990. "Undocumented Migration to the United States: Evidence from a Repeated Trials Model”, pp. 159-82 in Undocumented Migration to the United States: IRCA and the Experience of the 1980s, edited by Frank D. Bean, Barry Edmonston, and Jeffrey S. Passel. Washington, DC: Urban Institute.

Espenshade, Thomas J. 1994. "Does the Threat of Border Apprehension Deter Undocumented U.S. Immigration?” Population and Development Review, 20(4): 871-92.

Finch BK, Catalano RC, Novaco RW, Vega WA. 2003. "Employment frustration and alcohol abuse/dependence among labor migrants in California” Journal of Immigration Health, 5(4): 181-186.

Finch BK, Hummer RA, Kolody Bo, Vega WA. 2001. "The role of discrimination and acculturative stress in the physical health of Mexican-origin adults" Hispanic Journal of Behavioral Sciences, 23(4): 399-429.

Finch BK, Vega WA. 2003. “Acculturation stress, social support, and self-rated health among Latinos in California” Journal of Immigrant Health, 5(3): 109-117.

Gonzalez de la Rocha, Mercedes and Agustin Escobar Latapi. 1990. "The Impact of IRCA on the Migration Patterns of a Community in Los Altos, Jalisco, Mexico”, Working Paper No. 41, Commission for the Study of International Migration and Cooperative Economic Development.

Hagan, Jacqueline, Brianna Castro and Nestor Rodriguez. 2010. "The Effects of U.S. Deportation Policies on Immigrant Families and Communities: Cross-Border Perspectives", North Carolina Law Review, 88(5): 1799-1823.

Hagan, Jacqueline, Karl Eschbach and Nestor Rodriguez. 2008. "U.S. Deportation Policy, Family Separation, and Circular Migration”, International Migration Review, 42(1): 64-88. 
Hanson, Gordon H. and Antonio Spilimbergo. 1999. "Illegal Immigration, Border Enforcement, and Relative Wages: Evidence from Apprenhensions at the U.S.-Mexico Border”, American Economic Review, 89(5): 1337-57.

Kaiser Commission on Medicaid and the Uninsured. 2003. "Immigrants' Health Care Coverage and Access", available at: www.kff.org.

Kossoudji, Sherrie A. 1992. "Playing Cat and Mouse at the U.S.-Mexican Border", Demography, 29(2): 159-80.

Ku, Leighton. 2009. "Changes in Immigrants' Use of Medicaid and Food Stamps: The Role of Eligibility and Other Factors", pp. 153-92 in Immigrants and Welfare: The Impact of Welfare Reform on America's Newcomers, edited by Michael Fix. New York, NY: Russell Sage Foundation.

Kullgren, Jeffrey T. 2003. "Restrictions on Undocumented Immigrants' Access to Health Services: The Publick Health Implications of Welfare Reform", American Journal of Public Health, 93(10): 1630-33.

Lindstrom, David P. 1996. "Economic Opportunity in Mexico and Return Migration From the United States,” Demography, 33(3): 357-374.

Lofstrom, Magnus, Sarah Bohn and Steven Raphael. 2011. Lessons from the 2007 Legal Arizona Workers Act. Public Policy Institute, California.

Lowell, B. Lindsay and Rodolfo O. de la Garza. 2002. "The Development Role of Remittances in U.S. Latino Communities and in Latin American Countries.” In Sending Money Home, edited by R. de la Garza and B. L. Lowell, Rowman \& Littlefield Publishers Inc., Oxford, England, pp. 3-27.

Marin G, Sabogal F, Marin BV, Otero-Sabogal R, Perez-Stable E. 1987. "Development of a short acculturation scale" Hispanic Journal of Behavioral Sciences, 9: 183-205.

Massey, Douglas S., Katherine M. Donato, and Zai Liang. 1990. "Effects of the Immigration Reform and Control Act of 1986: Preliminary Data from Mexico", pp. 182-210 in Undocumented Migration to the United States: IRCA and the Experience of the 1980s, edited by Frank D. Bean, Barry Edmonston, and Jeffrey S. Passel. Washington, DC: Urban Institute.

Massey, Douglas S., Jorge Durand, and Nolan J. Malone. 2002. Beyond smoke and mirrors: Mexican immigration in an era of economic integration. New York: Russell Sage Foundation.

Menjivar, Cecilia and Leisy Abrego. 2012. "Legal Violence: Immigration Law and the Lives of Central American Immigrants”, American Journal of Sociology, 117(5): 1380-1421.

Norris A, Ford K, Bova C. 1996. "Psychometrics of a brief acculturation scale for Hispanics in a probability sample of urban Hispanic adolescents and young adults" Hispanic Journal of Behavior Science, 18: 29-38. 
Office of Immigration Statistics. 2010. 2010 Yearbook of Immigration Statistics. U.S. Department of Homeland Security.

Orrenius, Pia M. 1999. Return Migration from Mexico: Theory and Evidence. Ph.D, Dissertation, University of California, Los Angeles.

Orrenius, Pia M. 2001. "Illegal immigration and enforcement along the U.S.-Mexico border; an overview," Economic and Financial Policy Review, Federal Reserve Bank of Dallas, issue Q I, pages 2-11.

Orrenius, Pia M., and Madeline Zavodny. 2003. "Do Amnesty Programs Reduce Undocumented Immigration? Evidence from IRCA”, Demography, 40(3): 437-50.

Parrado, Emilio A. 2012. "Immigration Enforcement Policies, the Economic Recession, and the Size of Local Mexican Immigrant Populations", The Annals of the American Academy of Political and Social Science, 641: 16-37.

Passel, Jeffrey S. and D’Vera Cohn. 2011. “Unauthorized Immigrant Population: National and State Trends, 2010” Pew Hispanic Center.

Pew Hispanic Center. 2007. 2007 National Survey of Latinos: As Illegal Immigration Issue Heats Up, Hispanics Feel a Chill. Pew Hispanic Center.

Reyes, Belinda. 1997. "Dynamics of Immigration: Return Migration to Western Mexico", Public Policy Institute of California.

Ritcher, Susan M., J. Edward Taylor, and Antonio Yunez-Naude. 2007. "Impacts of Policy Reforms on Labor Migration from Rural Mexico to the United States" in Mexican Immigration to the United States, George J. Borjas, ed., National Bureau of Economic Research Conference Report.

Rivers, Patrick A., Fausto G. Patino. 2006. "Barriers to Health Care Access for Latino Immigrants in the USA”, International Journal of Social Economics, 33(3): 207-220.

Rosenblum, Marc R. 2011. E-Verify: Strengths, Weaknesses, and Proposals for Reform. Washington, DC: Migration Policy Institute.

Rosenblum, Marc R., and Leo B. Gorman. 2010. "The Public Policy Implications of StateLevel Worksite Migration Enforcement: The Experiences of Arizona, Mississippi, and Illinois”, In Taking Local Control: Immigration Policy Activism in U.S. Cities and States, edited by Monica W. Varsanyi, Stanford: Stanford University Press. pp. 115-134.

Schur, Claudia L., and Leigh Ann Albers. 1996. "Language, Sociodemographics, and Health Care Use of Hispanic Adults”, Journal of Health Care for the Poor and Underserved, 7:140-158. 
Secretaría de Gobernación, Consejo Nacional de Población, Instituto Nacional de Migración, Secretaría de Relaciones Exteriores, Secretaría del Trabajo y Previsión Social, El Colegio de la Frontera Norte. 2007. Encuesta sobre migración en la Frontera Norte de Mexico, Serie Anualizada 2000-2007.

Sherry, A. 2004. Foundations of U.S. "Immigration Control Policy: A Study of Information Transmission to Mexican Migrants.” San Diego: University of California-San Diego, Center for Comparative Immigration Studies, Working Paper No. 95, online at htpp://www.ccisucsd.org/PUBLICATIONS/wrkg95.pdf

Singer, Autrey, and Douglas S. Massey. 1988. “The Social Process of Undocumented Border Crossing Among Mexican Migrants”, International Migration Review, 32(Fall): 561-92.

Solis, Julia M., Gary Marks, Melinda Garcia, and David Shelton. 1990. “Acculturation, Access to Care, and Use of Preventive Services by Hispanics: Findings from HHANES 19821984”, American Journal of Public Health, 80: 11-19.

Spener, D. 2001. "Smuggling Migrants through South Texas: Challenges Posed by Operation Rio Grande” in Kyle, D. and Snyder, T. (eds), Global Human Smuggling: Comparative Perspectives. Baltimore: John Hopkins University Press, 129-65.

Varsanyi, Monica W. (Ed.) 2010. Taking Local Control: Immigration Policy Activism in U.S. Cities and States. Stanford: Stanford University Press.

Wallen GR, Feldman RH, Anliker J. 2002. "Measuring acculturation among Central American women with the use of a brief scale” Journal of Immigrant Health, 4(2): 95-102.

Westat Corporation. 2009. "Findings of the E-Verify Program Evaluation.” Report submitted to Department of Homeland Security. Available at: http://www.uscis.gov/USCIS/E-Verify/EVerify/Final\%20E-Verify\%20Report\%2012-16-09_2.pdf

White, Michael J., Frank D. Bean, and Thomas J. Espenshade. 1990. “The U.S. 1986 Immigration Reform and Control Act and Undocumented Migration to the United States", Population Research and Policy Review, 9: 93-116.

Woloshin, Steven, Nina A. Bickell, Lisa M. Schwartz, Francesca Gany, and H. Gilbert Welch. 1995. "Language Barriers in Medicine in the United States", Journal of the American Medical Association, 273(9): 724-728.

Wooldridge, Jeffrey M. 2008. Introductory Econometrics: A Modern Approach (4 ${ }^{\text {th }}$ ed.). Ohio: South-Western Cengage Learning. 
Table 1: Means and Standard Deviations of Key Regressors

\begin{tabular}{|c|c|c|c|c|}
\hline \multirow[b]{2}{*}{ Variables } & \multicolumn{2}{|c|}{ Deported Sample } & \multicolumn{2}{|c|}{ Voluntary Returnee Sample } \\
\hline & Observations & $\begin{array}{c}\text { Mean } \\
\text { (Std. Dev.) }\end{array}$ & Observations & $\begin{array}{c}\text { Mean } \\
\text { (Std. Dev.) }\end{array}$ \\
\hline Age & 947 & $\begin{array}{l}31.53 \\
(8.78)\end{array}$ & 286 & $\begin{array}{l}31.77 \\
(9.98)\end{array}$ \\
\hline Male & 947 & $\begin{array}{c}0.94 \\
(0.24)\end{array}$ & 286 & $\begin{array}{c}0.92 \\
(0.27)\end{array}$ \\
\hline No Education & 947 & $\begin{array}{c}0.03 \\
(0.18)\end{array}$ & 286 & $\begin{array}{c}0.02 \\
(0.13)\end{array}$ \\
\hline Primary Education (Elementary School) & 947 & $\begin{array}{c}0.34 \\
(0.48)\end{array}$ & 286 & $\begin{array}{c}0.33 \\
(0.47)\end{array}$ \\
\hline Secondary Education (Middle School) & 947 & $\begin{array}{c}0.37 \\
(0.48)\end{array}$ & 286 & $\begin{array}{c}0.36 \\
(0.48)\end{array}$ \\
\hline Preparatoria (High School) & 947 & $\begin{array}{c}0.21 \\
(0.41)\end{array}$ & 286 & $\begin{array}{c}0.24 \\
(0.43)\end{array}$ \\
\hline Higher Education (More than High School) & 947 & $\begin{array}{c}0.04 \\
(0.19)\end{array}$ & 286 & $\begin{array}{c}0.05 \\
(0.22)\end{array}$ \\
\hline Married & 947 & $\begin{array}{l}0.47 \\
(0.5)\end{array}$ & 286 & $\begin{array}{c}0.6 \\
(0.49)\end{array}$ \\
\hline Lived with Partner while in the U.S. & 947 & $\begin{array}{c}0.38 \\
(0.49)\end{array}$ & 286 & $\begin{array}{l}0.47 \\
(0.5)\end{array}$ \\
\hline Lived with Kids while in the U.S. & 947 & $\begin{array}{c}0.23 \\
(0.42)\end{array}$ & 286 & $\begin{array}{c}0.13 \\
(0.34)\end{array}$ \\
\hline Previous Number of Crossings & 915 & $\begin{array}{c}4.26 \\
(20.94)\end{array}$ & 264 & $\begin{array}{c}39.06 \\
(187.2)\end{array}$ \\
\hline Previous Number of Deportations & 918 & $\begin{array}{c}2.35 \\
(3.14)\end{array}$ & 264 & $\begin{array}{c}40.69 \\
(195.98)\end{array}$ \\
\hline Worked in the U.S. Last & 947 & $\begin{array}{c}0.28 \\
(0.45)\end{array}$ & 286 & $\begin{array}{c}0.23 \\
(0.42)\end{array}$ \\
\hline Lived in Poor Housing while in the U.S. & 947 & $\begin{array}{c}0.03 \\
(0.18)\end{array}$ & 286 & $\begin{array}{c}0.03 \\
(0.17)\end{array}$ \\
\hline Length of Stay in the U.S. Last & 872 & $\begin{array}{c}2729.71 \\
(2974.89)\end{array}$ & 286 & $\begin{array}{l}2135.62 \\
(2390.6)\end{array}$ \\
\hline Year Last Crossed to the U.S. & 900 & $\begin{array}{c}2005.31 \\
(6.26)\end{array}$ & 257 & $\begin{array}{c}2005.99 \\
(4.25)\end{array}$ \\
\hline E-Verify State & 947 & $\begin{array}{c}0.09 \\
(0.28)\end{array}$ & 286 & $\begin{array}{c}0.06 \\
(0.23)\end{array}$ \\
\hline
\end{tabular}


Table 2: Incidence of Difficulties among Deported and Voluntary Returnees

\begin{tabular}{lccc}
\hline \hline Variables & Deported & Voluntary Returnees & t-stat \\
\hline Difficulties in Getting Government Assistance & 0.33 & 0.31 & 0.86 \\
Difficulties in Finding Legal Services & $(0.47)$ & $(0.46)$ & $1.78^{*}$ \\
Difficulties in Obtaining Healthcare Services & 0.23 & 0.18 & 0.06 \\
Fear of Deportation & $(0.42)$ & $(0.39)$ & 0.75 \\
Moved Across States & 0.18 & 0.17 & $1.96^{* *}$ \\
Plant to Come Back to the U.S. in the Near Future & $(0.38)$ & $(0.38)$ & $2.07^{* *}$ \\
Observations & 0.50 & 0.47 & \\
\hline \hline
\end{tabular}

Notes: Standard deviations are in parentheses. The null hypothesis being tested is whether the means of those deported and the means of the voluntary returnees are the same. ***, **, * denote $1 \%, 5 \%$, and $10 \%$ levels of significance, respectively. 
Table 3: Likelihood of Experiencing Any of the Following While in the United States

\begin{tabular}{|c|c|c|c|c|c|c|c|c|}
\hline \multirow{2}{*}{$\begin{array}{l}\text { Sample } \\
\text { Independent Variables }\end{array}$} & \multicolumn{4}{|c|}{ Deported } & \multicolumn{4}{|c|}{ Voluntary Returnees } \\
\hline & $\begin{array}{l}\text { Difficulties with } \\
\text { Government } \\
\text { Assistance }\end{array}$ & $\begin{array}{l}\text { Difficulties with } \\
\text { Legal Services }\end{array}$ & $\begin{array}{l}\text { Difficulties with } \\
\text { Healthcare } \\
\text { Services }\end{array}$ & $\begin{array}{c}\text { Fear of } \\
\text { Deportation }\end{array}$ & $\begin{array}{l}\text { Difficulties with } \\
\text { Government } \\
\text { Assistance }\end{array}$ & $\begin{array}{l}\text { Difficulties with } \\
\text { Legal Services }\end{array}$ & $\begin{array}{c}\text { Difficulties with } \\
\text { Healthcare } \\
\text { Services }\end{array}$ & $\begin{array}{c}\text { Fear of } \\
\text { Deportation }\end{array}$ \\
\hline Constant & $0.87 * * *$ & $1.00 * * *$ & $1.10^{* * *}$ & $0.72 * * *$ & -0.59 & -0.23 & 0.08 & -0.86 \\
\hline \multirow[t]{2}{*}{ Age } & 0.001 & -0.001 & -0.001 & 0.0002 & 0.002 & 0.001 & 0.002 & -0.01 \\
\hline & $(0.002)$ & $(0.002)$ & $(0.002)$ & $(0.002)$ & $(0.004)$ & $(0.003)$ & $(0.003)$ & $(0.004)$ \\
\hline \multirow[t]{2}{*}{ Male } & -0.09 & -0.02 & 0.04 & -0.02 & 0.13 & 0.07 & -0.02 & 0.05 \\
\hline & $(0.07)$ & $(0.06)$ & $(0.05)$ & $(0.07)$ & $(0.11)$ & $(0.08)$ & $(0.11)$ & $(0.14)$ \\
\hline \multirow[t]{2}{*}{ Secondary Education } & -0.03 & -0.03 & $-0.06 *$ & -0.03 & 0.06 & 0.05 & 0.01 & 0.01 \\
\hline & $(0.04)$ & $(0.04)$ & $(0.03)$ & $(0.04)$ & $(0.08)$ & $(0.07)$ & $(0.07)$ & $(0.09)$ \\
\hline \multirow[t]{2}{*}{ Preparatoria } & -0.01 & $-0.07^{*}$ & -0.05 & 0.01 & -0.01 & 0.07 & $-0.14 * *$ & -0.08 \\
\hline & $(0.05)$ & $(0.04)$ & $(0.04)$ & $(0.05)$ & $(0.10)$ & $(0.08)$ & $(0.07)$ & $(0.10)$ \\
\hline \multirow[t]{2}{*}{ Higher Education } & -0.003 & -0.02 & -0.03 & 0.04 & $-0.24^{* *}$ & $-0.26 * * *$ & -0.15 & -0.17 \\
\hline & $(0.09)$ & $(0.09)$ & $(0.08)$ & $(0.11)$ & $(0.10)$ & $(0.08)$ & $(0.13)$ & $(0.14)$ \\
\hline \multirow[t]{2}{*}{ Married } & 0.01 & 0.01 & 0.05 & 0.06 & 0.03 & -0.07 & -0.04 & $0.24^{* * *}$ \\
\hline & $(0.04)$ & $(0.03)$ & $(0.03)$ & $(0.04)$ & $(0.07)$ & $(0.06)$ & $(0.06)$ & $(0.08)$ \\
\hline Lived with Partner while in the U.S. & $0.12^{* * *}$ & $0.13^{* * *}$ & 0.06 & $0.16^{* * *}$ & -0.05 & 0.06 & 0.0567 & -0.01 \\
\hline \multirow[t]{2}{*}{ Lived with Kids while in the U.S. } & $0.11^{* *}$ & $0.09 * *$ & $0.08^{*}$ & $0.14 * * *$ & -0.05 & $0.27 * * *$ & $0.16^{*}$ & 0.05 \\
\hline & $(0.05)$ & $(0.05)$ & $(0.04)$ & $(0.05)$ & $(0.11)$ & $(0.11)$ & $(0.10)$ & $(0.12)$ \\
\hline \multirow[t]{2}{*}{ Previous Number of Crossings } & 0.003 & 0.004 & $0.006^{* *}$ & -0.002 & -0.01 & $-0.01^{*}$ & -0.01 & -0.01 \\
\hline & $(0.003)$ & $(0.003)$ & $(0.002)$ & $(0.004)$ & $(0.01)$ & $(0.01)$ & $(0.01)$ & $(0.01)$ \\
\hline \multirow[t]{2}{*}{ Previous Number of Deportations } & -0.01 & -0.007 & $-0.01 * * *$ & -0.001 & 0.02 & $0.02 * *$ & $0.02 * *$ & $0.03^{* * *}$ \\
\hline & $(0.01)$ & $(0.006)$ & $(0.004)$ & $(0.01)$ & $(0.01)$ & $(0.01)$ & $(0.01)$ & $(0.01)$ \\
\hline \multirow[t]{2}{*}{ Worked in the U.S. Last } & $0.11^{* *}$ & 0.04 & 0.04 & $0.09 * *$ & 0.14 & 0.07 & 0.13 & 0.05 \\
\hline & $(0.04)$ & $(0.04)$ & $(0.04)$ & $(0.04)$ & $(0.09)$ & $(0.08)$ & $(0.08)$ & $(0.10)$ \\
\hline \multirow[t]{2}{*}{ Lived in Poor Housing while in the U.S. } & $0.18^{*}$ & 0.01 & 0.08 & 0.02 & 0.29 & 0.22 & $0.40 * *$ & 0.19 \\
\hline & $(0.10)$ & $(0.09)$ & $(0.09)$ & $(0.11)$ & $(0.24)$ & $(0.20)$ & $(0.20)$ & $(0.21)$ \\
\hline Length of Stay in the U.S. Last & $\begin{array}{l}-2.80 \mathrm{e}-06 \\
(7.60 \mathrm{e}-06)\end{array}$ & $\begin{array}{c}3.67 \mathrm{e}-06 \\
(6.64 \mathrm{e}-06)\end{array}$ & $\begin{array}{c}2.63 \mathrm{e}-06 \\
(6.35 \mathrm{e}-06)\end{array}$ & $\begin{array}{c}8.45 \mathrm{e}-06 \\
(7.99 \mathrm{e}-06)\end{array}$ & $\begin{array}{c}-2.14 \mathrm{e}-05 \\
(1.73 \mathrm{e}-05)\end{array}$ & $\begin{array}{c}\text { 8.18e-06 } \\
(1.38 \mathrm{e}-05)\end{array}$ & $\begin{array}{c}-2.05 \mathrm{e}-06 \\
(1.29 \mathrm{e}-05)\end{array}$ & $\begin{array}{l}1.01 \mathrm{e}-05 \\
(2.20 \mathrm{e}-05)\end{array}$ \\
\hline \multirow[t]{2}{*}{ E-Verify State } & 0.21 & -0.22 & -0.18 & -0.06 & -0.40 & -0.60 & -0.48 & $2.82 * * *$ \\
\hline & $(0.25)$ & $(0.23)$ & $(0.23)$ & $(0.21)$ & $(0.50)$ & $(0.43)$ & $(0.40)$ & $(0.54)$ \\
\hline Time Fixed-Effects & \multicolumn{4}{|c|}{ Yes } & \multicolumn{4}{|c|}{ Yes } \\
\hline State Fixed-Effects & \multicolumn{4}{|c|}{ Yes } & \multicolumn{4}{|c|}{ Yes } \\
\hline
\end{tabular}

Notes: Robust standard errors are in parentheses. ${ }^{* * *}, * *, *$ denote $1 \%, 5 \%$, and $10 \%$ levels of significance, respectively. 
Table 4: Likelihood of Moving Across States

\begin{tabular}{|c|c|c|}
\hline Sample & Deported & Voluntary Returnees \\
\hline Independent Variables & $\begin{array}{c}\text { Coefficient } \\
\text { (Robust S.E.) }\end{array}$ & $\begin{array}{c}\text { Coefficient } \\
\text { (Robust S.E.) }\end{array}$ \\
\hline \multirow[t]{2}{*}{ Constant } & $0.80 * *$ & 0.13 \\
\hline & $(0.40)$ & $(0.37)$ \\
\hline \multirow[t]{2}{*}{ Age } & 0.001 & -0.002 \\
\hline & $(0.002)$ & $(0.002)$ \\
\hline \multirow[t]{2}{*}{ Male } & -0.07 & $0.07 * *$ \\
\hline & $(0.06)$ & $(0.03)$ \\
\hline \multirow[t]{2}{*}{ Secondary Education } & -0.05 & -0.02 \\
\hline & $(0.03)$ & $(0.03)$ \\
\hline \multirow[t]{2}{*}{ Preparatoria } & -0.04 & 0.001 \\
\hline & $(0.03)$ & $(0.04)$ \\
\hline \multirow[t]{2}{*}{ Higher Education } & $-0.11^{*}$ & -0.003 \\
\hline & $(0.06)$ & $(0.04)$ \\
\hline \multirow[t]{2}{*}{ Married } & -0.04 & 0.02 \\
\hline & $(0.03)$ & $(0.04)$ \\
\hline \multirow[t]{2}{*}{ Lived with Partner while in the U.S. } & $-0.19 * * *$ & 0.02 \\
\hline & $(0.03)$ & $(0.04)$ \\
\hline \multirow[t]{2}{*}{ Lived with Kids while in the U.S. } & $-0.16^{* * *}$ & 0.07 \\
\hline & $(0.03)$ & $(0.05)$ \\
\hline \multirow[t]{2}{*}{ Previous Number of Crossings } & -0.002 & -0.01 \\
\hline & $(0.002)$ & $(0.01)$ \\
\hline \multirow[t]{2}{*}{ Previous Number of Deportations } & -0.001 & -0.003 \\
\hline & $(0.004)$ & $(0.003)$ \\
\hline \multirow[t]{2}{*}{ Worked in the U.S. Last } & -0.04 & 0.05 \\
\hline & $(0.03)$ & $(0.04)$ \\
\hline \multirow[t]{2}{*}{ Lived in Poor Housing while in the U.S. } & -0.04 & -0.07 \\
\hline & $(0.09)$ & $(0.07)$ \\
\hline \multirow[t]{2}{*}{ Length of Stay in the U.S. Last } & $-2.67 e-05 * * *$ & $-6.48 e-06$ \\
\hline & $(4.55 \mathrm{e}-06)$ & (7.76e-06) \\
\hline \multirow[t]{2}{*}{ E-Verify State } & -0.19 & $-1.22 * * *$ \\
\hline & $(0.22)$ & $(0.26)$ \\
\hline Time Fixed-Effects & Yes & Yes \\
\hline State Fixed-Effects & Yes & Yes \\
\hline State-level Time Trends & Yes & Yes \\
\hline Observations & 825 & 255 \\
\hline R-Squared & 0.26 & 0.52 \\
\hline
\end{tabular}

Notes: Robust standard errors are in parentheses. ***, **, * denote 1\%, 5\%, and 10\% levels of significance, respectively. 
Table 5: Likelihood of Planning to Come Back to the United States in the Near Future

\begin{tabular}{|c|c|}
\hline Independent Variables & "Coefficient (Robust S.E.) \\
\hline Constant & $\begin{array}{c}1.01^{* * * *} \\
(0.29)\end{array}$ \\
\hline Age & $\begin{array}{l}-0.003^{*} \\
(0.002)\end{array}$ \\
\hline Male & $\begin{array}{l}-0.01 \\
(0.05)\end{array}$ \\
\hline Secondary Education & $\begin{array}{l}0.001 \\
(0.03)\end{array}$ \\
\hline Preparatoria & $\begin{array}{l}0.06^{*} \\
(0.04)\end{array}$ \\
\hline Higher Education & $\begin{array}{l}-0.01 \\
(0.07)\end{array}$ \\
\hline Married & $\begin{array}{c}0.02 \\
(0.03)\end{array}$ \\
\hline Lived with Partner while in the U.S. & $\begin{array}{c}0.15^{* * *} \\
(0.03)\end{array}$ \\
\hline Lived with Kids while in the U.S. & $\begin{array}{c}0.22 * * * \\
(0.04)\end{array}$ \\
\hline Previous Number of Crossings & $\begin{array}{c}0.003 \\
(0.003)\end{array}$ \\
\hline Previous Number of Deportations & $\begin{array}{c}0.016^{* * *} \\
(0.01)\end{array}$ \\
\hline Worked in the U.S. Last & $\begin{array}{c}0.02 \\
(0.04)\end{array}$ \\
\hline Lived in Poor Housing while in the U.S. & $\begin{array}{c}0.01 \\
(0.09)\end{array}$ \\
\hline Length of Stay in the U.S. Last & $\begin{array}{c}1.70 \mathrm{e}-05^{* * *} \\
(6.54 \mathrm{e}-06)\end{array}$ \\
\hline Deported & $\begin{array}{c}0.35^{* * *} \\
(0.02)\end{array}$ \\
\hline E-Verify State & $\begin{array}{c}0.03 \\
(0.19)\end{array}$ \\
\hline E-Verify State*Deported & $\begin{array}{c}-0.26 * * * \\
(0.09)\end{array}$ \\
\hline $\begin{array}{l}\text { Time Fixed-Effects } \\
\text { State Fixed-Effects } \\
\text { State-level Time Trends }\end{array}$ & $\begin{array}{l}\text { Yes } \\
\text { Yes } \\
\text { Yes }\end{array}$ \\
\hline $\begin{array}{l}\text { Observations } \\
\text { R-Squared }\end{array}$ & $\begin{array}{r}1092 \\
0.34\end{array}$ \\
\hline
\end{tabular}

Notes: The regression also includes dummy variables for those resided most of the time in several States. Observations in the regression contain all undocumented immigrants in our sample, both voluntary returnees and the deportees. Robust standard errors are in parentheses. $* * *, * *, *$ denote $1 \%, 5 \%$, and $10 \%$ levels of significance, respectively. 


\section{Appendix Survey Methodology}

The survey uses methods suited to the observation of migrant flows modeled after the EMIF, which relies on the following premises: (a) migrants represent mobile units that can be intercepted in certain times and places; (b) the vast majority (over 90\%) of migrants traveling across the US-Mexico border do so through eight Mexican border cities, one of them being Tijuana, Mexico; (c) migrants arrive at these border cities from other regions in Mexico through specific crossing areas (e.g. airports, bus stations, and migration facilities) identified through formative research; (d) after returning from the United States, migrants depart from these border cities to other regions in Mexico through the same crossing areas; (e) within these venues there are specific sites (e.g., gates, doorways, etc.) migrants necessarily cross by when arriving or departing from these border cities; (f) observation and screening for migration status of individuals crossing in these specific sites allows an accurate enumeration, sampling, and characterization of the migrant population traveling through the United States-Mexico border.

Specifically, a multi-stage sampling design with two dimensions and several stages within each dimension is employed. The geographic dimension takes into account the region, city within the region, area within the region, and site within the area where the migrant is intercepted. The sampling areas are defined as facilities through which migrants typically pass when arriving at Tijuana, such as the Tijuana International Airport, the Tijuana Central bus station, and the San Ysidro deportation station in the San Diego-Tijuana border. The temporal dimension consists of the quarter of the year, day of the week, and survey shift (i.e., each day was divided in 8-hour shifts) when the respondents are intercepted. Every 3 months, a random sample of sampling pairs "place-time" was generated to determine the specific combinations of sites and times where and when the survey was to be conducted during the following three months. The weighting procedures take into account that not all individuals have equal probability of being selected and included in the survey, and adjust for this unequal probability. Moreover, the survey weights include expansion factors to reflect the volume of migrants traveling through each sampling site during specific time periods. This information is also used to estimate the size of the population represented by the study sample.

For weight computation, the survey uses an adapted version of a formula developed by researchers at El Colegio de la Frontera Norte and used routinely for computing survey weights for the EMIF. The formula follows the logic behind standard weighting procedures for surveys using multistage sampling methods and has been adapted to reflect the specific sampling design of our survey. Each observation is assigned a weight W, which is calculated as follows:

$\mathrm{W}=\left[(\mathrm{k} / \mathrm{n}) * \mathrm{pPoint}^{*} \mathrm{pSite} * \text { pCity } * \mathrm{pRegion}^{*} \mathrm{pShift}_{\mathrm{D}} * \mathrm{pDay}_{\mathrm{S}} * \mathrm{pStudy}\right]^{-1}$,

where $k$ is the number of individuals who crossed by the sampling shift, were screened for participation in the survey, and did not meet eligibility criteria or refused to participate; for deported migrants, $n$ is the number of persons released by Mexican migration officers within the sampling shift when the questionnaire was administered; for sites other than the deportation site, $\mathrm{n}$ reflects the number of persons traveling through the sampling site from the beginning of the sampling shift to the end of the administration of the first questionnaire (for the first respondent) 
and from the end of the administration of the first questionnaire to the end of the administration of the second questionnaire (for the second respondent), and so on; pPoint equals the proportion of individuals traveling through the sampling point relative to the estimated total volume of individuals traveling through the sampling site where the point is located; $p$ Site representes the proportion of individuals traveling through the sampling site relative to the estimated total flow traveling through the city where the site is located; unlike for the EMIF, $p$ City, and pRegion are both equal 1, given that the city (i.e. Tijuana) is only one, and the region (i.e. West US-Mexico border) is only one and they are all included with probability equal 1 in the sampling design; $\left(\text { pShift }_{D}\right)^{-1}$ is the probability of selecting the sampling shift of all possible sampling shifts on a day; $\left(\mathrm{pDay}_{\mathrm{s}}\right)^{-1}$ is calculated for each day of the week (i.e. Mondays, Tuesdays, etc.) and reflects the probability of selecting each day of the week considering the total number of Mondays, Tuesdays, etc. included in the period during which the survey was implemented; and pStudy is equal to 1 , given that the study period was included with probability 1 in the sampling frame.

At the beginning of each sampling shift at each sampling site, an interviewer intercepted the first adult-looking subject who crossed by the sampling site and applied a screening intercept survey to determine if he/she qualified as a migrant. If the participant did not meet the inclusion criteria, the interviewer intercepted the next adult-looking person crossing by the sampling site and repeated the process. For the current study, we focused on migrants who were returning to the U.S. either voluntarily or via deportation not born in the United States and 18 years of age or older. A short screening survey determined eligibility. 
Appendix Table

Table A: Variable Names and Definitions

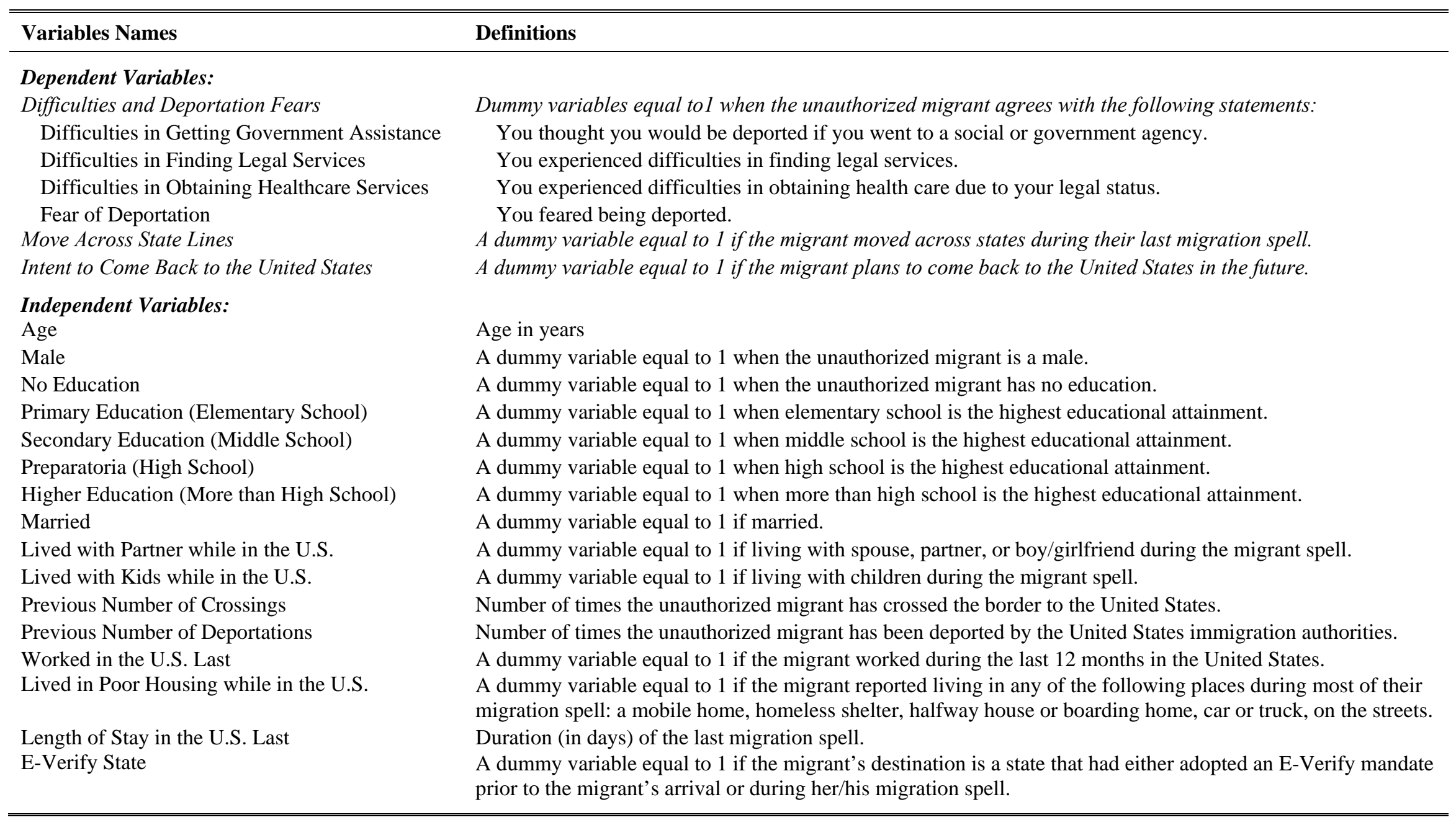

